\title{
Time resolved measure of coronary sinus flow following regadenoson administration
}

\author{
O Julian Booker, Patricia Bandettini, Peter Kellman, Joel Wilson, Steve Leung, Sujethra Vasu, Sujata Shanbhag, \\ Jennifer Henry, Tracy Lowrey, Christine Mancini, Andrew E Arai
}

From 2011 SCMR/Euro CMR Joint Scientific Sessions

Nice, France. 3-6 February 2011

\section{Objective}

To use velocity encoded phase contrast MRI to determine timing of peak myocardial blood flow to establish when CMR stress perfusion imaging should be performed after injection of regadenoson.

\section{Background}

Regadenoson is a selective A2A adenosine receptor agonist recently FDA approved for stress testing. The package insert recommends administration of the radionuclide imaging agent 20 seconds after bolus. Optimal timing of CMR first-pass perfusion imaging has not been established.

\section{Methods}

CMR was performed on eighteen volunteers with 10-year Framingham risk scores $<1 \%$ (15 m, $23 \pm 7$ years) using a $1.5 \mathrm{~T}$ Siemens Espree. Serial measures of coronary sinus (CS) and cardiac output (CO) were made using a velocity encoded phase contrast sequence.

\section{Results}

Peak CS flow occurred at $101.7 \pm 69.1$ seconds (median 75 seconds) which was significantly different than the recommended injection time of $20 \mathrm{sec}(\mathrm{p}<0.001)$. Flow at 90 seconds was also higher than at 30 seconds $(\mathrm{p}<0.001)$. CS flow decreased more rapidly than systemic flow and heart rate however none returned to baseline by 20 min. Figs 1, 2, 3, 4 .

\section{Conclusion}

Peak myocardial blood flow occurs later after injection of regadenoson than suggested in the package insert (median 75 or average 102 seconds vs 20 seconds).

National Heart, Lung, and Blood Institute, Bethesda, MD, USA
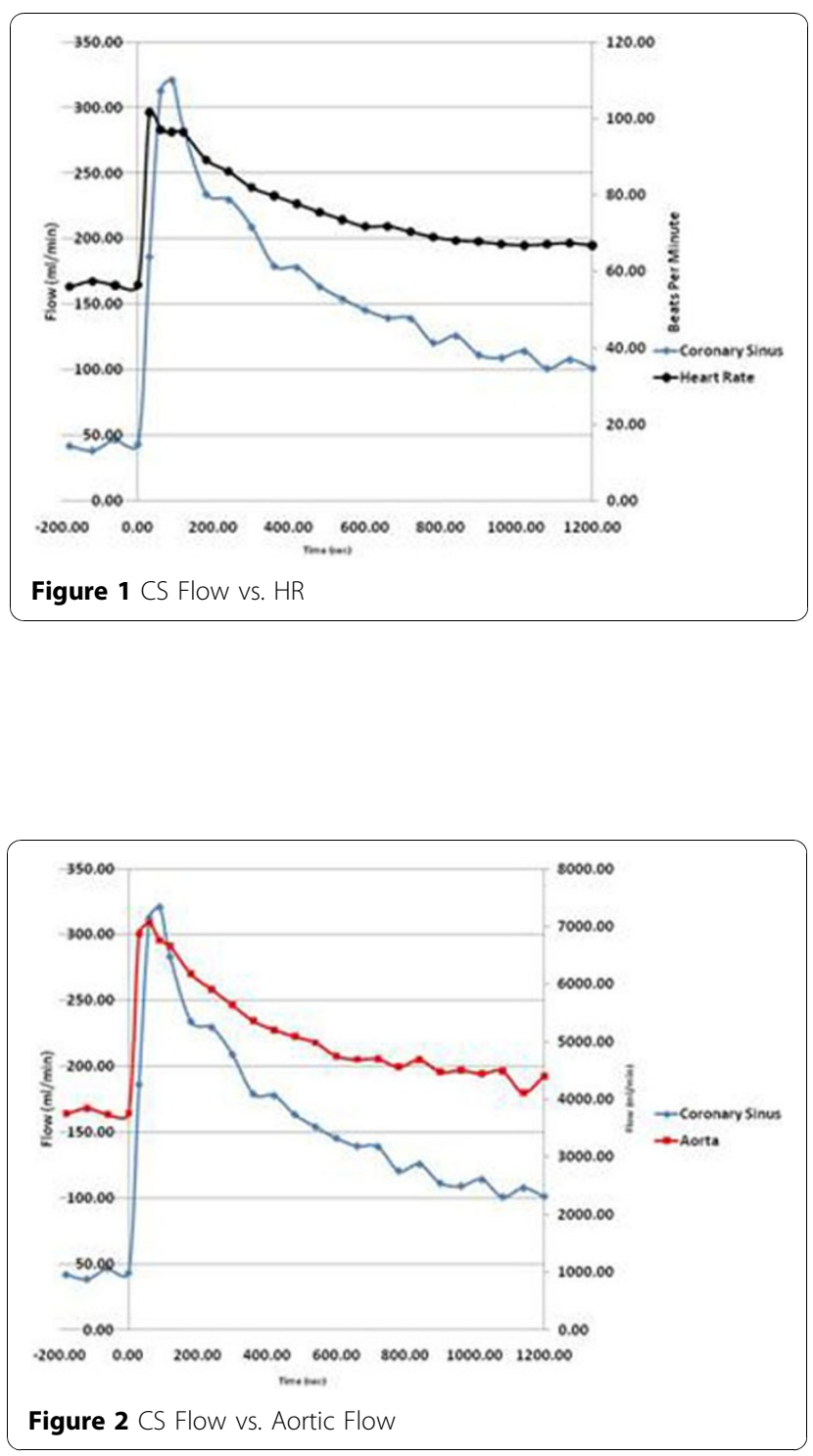

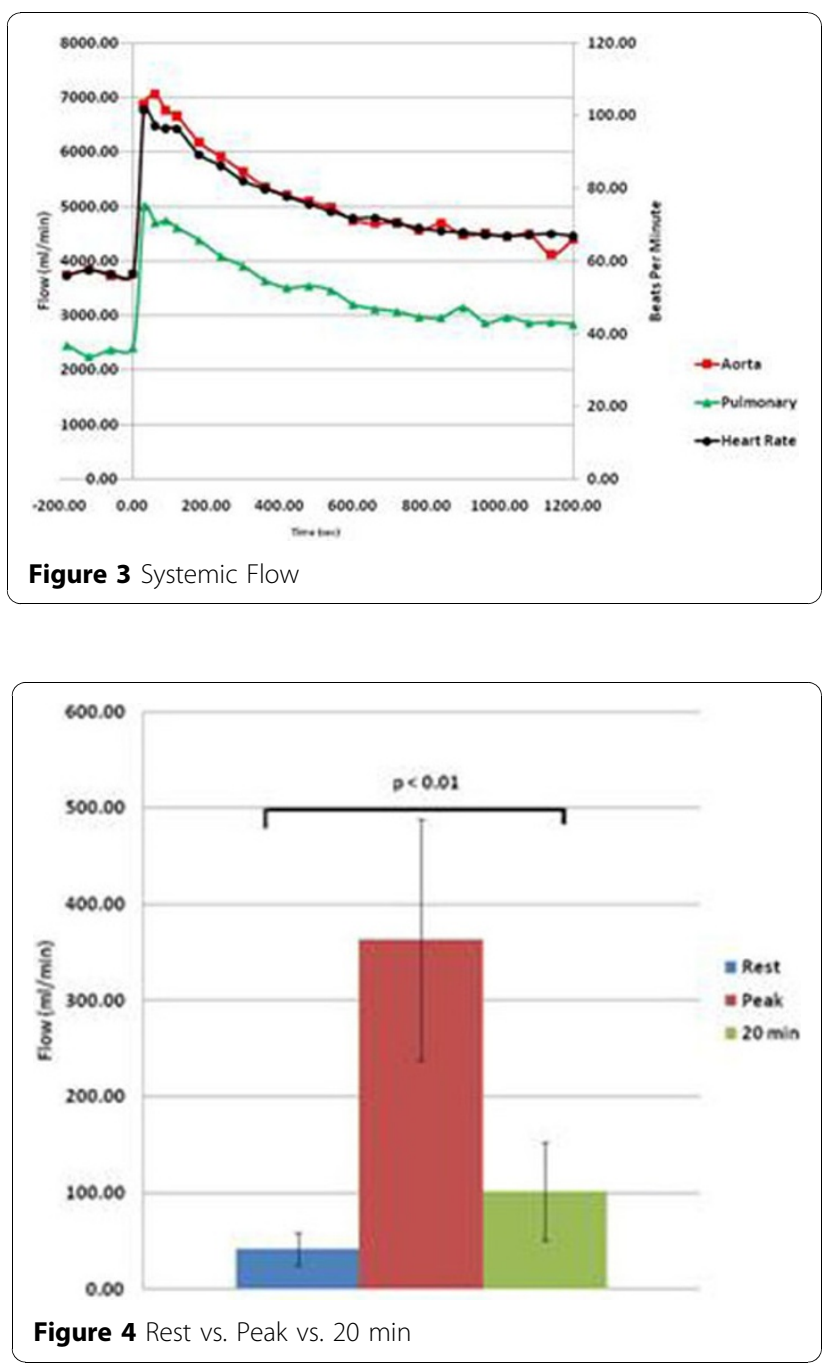

Optimizing the timing of first-pass perfusion imaging may improve sensitivity in the detection of coronary stenoses.

Published: 2 February 2011

doi:10.1186/1532-429X-13-S1-074

Cite this article as: Booker et al:: Time resolved measure of coronary

sinus flow following regadenoson administration. Journal of

Cardiovascular Magnetic Resonance 2011 13(Suppl 1):O74.
Submit your next manuscript to BioMed Central and take full advantage of:

- Convenient online submission

- Thorough peer review

- No space constraints or color figure charges

- Immediate publication on acceptance

- Inclusion in PubMed, CAS, Scopus and Google Scholar

- Research which is freely available for redistribution

Submit your manuscript at www.biomedcentral.com/submit
C Biomed Central 